\title{
Lagged R\&D spillovers and international competitiveness: \\ A sectoral approach in the case of Tunisia
}

\author{
Tarek Bel Hadj \\ Faculty of Management and Economics of Sfax
}

\begin{abstract}
In the developing countries, foreign technology was largely compared to the one of the principal engines of the economic growth. However, according to the economic literature, the assimilation of this technology is far from being an automatic process. If the developing countries (or firms located in such countries) are not able to satisfy the conditions which their make it possible to learn this technology, so that they are deprived of sufficient absorptive capacity, they will face difficulties to transform these spillovers into profits of competitiveness. Initially, we will analyze within this paper the interaction between absorptive capacity of R\&D spillovers and technological lag. In the second time, we will analyze the effects of the current and lagged R\&D spillovers on the international competitiveness measured by exports and this, in the specific context of Tunisia.
\end{abstract}

Keywords: R\&D spillovers, absorptive capacity, technological lag, competitiveness.

\section{Interaction between technological lag and absorptive capacity}

The technological lag can strongly affects the capacity of the countries to absorb the R\&D spillovers. This idea is conceived through the analysis of the race of the innovation and the role of the initial technological lag in the determination of the speed of catching up. Thus, a significant question can be raised: How we can characterize the evolution of the absorptive capacity of $R \& D$ spillovers along the catching up?

\subsection{The race of the innovation}

The theoretical literature which was focused on the race of the innovation can be organized around two principal models: Models "without memory" and models "with memory". The first line of studies (D. Lowery 1979 and T. Lee and L. Wilde 1980), postulates that the chances of success of a given firm are only dependent on its current activity of R\&D. In other words, competition in the race of the innovation can only relate to the identical firms. Moreover, in this type of models it is not possible to identify gaining in the race insofar as all entering are potential on the market. However, with the introduction of the R\&D spillovers and the absorptive capacity, the notion of the race of the innovation without memory remains unrealistic. In this direction, the models with memory took into account a significant aspect related to the lagged efforts in the R\&D which largely affect the probability of later discovery (C. Halfmanshlayer 2003).

To apprehend the important role of the absorptive capacity in the process of technological innovation, a strong articulation between the race of the innovation and the R\&D spillovers was emphasized. This idea is revealed through 
a significant aspect characterizing the follower and the leader: the lag in the experiment between the two parts. In this case, if the experiment ${ }^{1}$ of the follower and the leader is with identical steps, the two parts profit mutually from the $R \& D$ spillovers and each one of them prefers investing in $R \& D$ to be able to exceed the other part and to adapt the results of innovation (C. Hamenschlayer 2003). When the firms are equipped with the same level of experiment, the existence of $R \& D$ spillovers has positive repercussions on the $R \& D$ and it does not decrease in any manner their efforts as regards the $R \& D$ of the competitor. In other words, in the presence of the R\&D spillovers, the leader is brought to undertake the R\&D in an aggressive way to guarantee that the follower gives up the race. This maximum effort of R\&D on behalf of the leader creates a dynamics as regards innovation, thus, the number of the steps necessary to obtaining the patent is reduced, which increases the possibilities of innovation in industry. However, if the difference between the two parts is huge, the leader will not be constrained to enrich his knowledge by his follower by the totality of his effort, since in this context, it is not necessary to increase his advance.

C. Hamenschlayer (2003) distinguishes an intermediate case, when the proximity as regards R\&D between the follower and the leader is more or less high. In this case, the reactions will be differentiated according to the part in question. Under the effect of the R\&D spillovers, the leader prefers to invest heavily in $R \& D$ to delocalize and outdistance the follower from the race of the innovation. In absence of the R\&D spillovers, a moderated effort in R\&D is sufficient to widen the gap. The reactions of the follower are such as: In presence of a moderated effort, he invests as much as possible, and in presence of heavy investment in R\&D on behalf of the leader, he prefers to give up. In other words, competition in the race of the innovation does not stimulate always (ex-handle) the innovation and the expenditure of $R \& D$ under the effect of the $R \& D$ spillovers. This result contradicts the proposal of Klette and Griliches $(2000)^{2}$ because they neglect a significant aspect related to the spillovers of R\&D.

Therefore, the presence of the $R \& D$ spillovers widens the strategic dimension of the decisions specific to the R\&D of the firms, and the presence of the absorptive capacity facilitates the process of catching up between the follower and the leader. Moreover, the competitors adjust their strategies as the race develops, particularly with changes in their relative positions. The firms will vary their efforts which they are in a position at the head or delayed in the race (G. M. Grossman and C Shapiro 1987).

\subsection{Absorptive capacity and technological lag}

It was largely recommended that the possibilities of exploiting the potential of the catching up are higher for the countries having a relatively weak technological lag (M. Lankhuison 1998 and C Hamenschlayer 2003). This is completely contradictory with the conventional assumption of convergence. Indeed, starting from the assumption of convergence, the countries which are late behind the technological leader enjoy the advantages of "backwardness" (M. Laukhuizen 1998). The source of these advantages is based on opportunities which the follower has to assimilate the knowledge developed by the leader. In this case, technological progress can be generated by the development and the diffusion of new knowledge or new combinations of existing knowledge. This idea was supported since the new theory of growth (Romer 1990) in which knowledge take the form of a not rival good. In other words, once knowledge is produced, it can be reproduced at a weak or not additional cost. This implies that the countries placed behind the

\footnotetext{
${ }^{1}$ Measured by the accumulated knowledge compared to a date of reference.

${ }^{2}$ See proposal 6 in Klette and Griliches (2000):"Empirical patterns of firm growth and R\&D investment:A quality ladder model interpretation ", The Economic Journal, 110, pp. 363-387.
} 
technological border can profit from the spillovers of knowledge developed by the technological border. This is why, the innovation and technological progress in the advanced countries are dependent on the production of new knowledge as of the jumps of progress which results from this and which transmits to the followers.

Consequently, the followers can carry out a higher rate of technological progress and catch up to the leader. In this direction, the assumption of convergence implies that, under the effect of the dissemination of the information, as the initial technological lag is broad, higher is the potential of convergence ${ }^{3}$.

However, the exploitation of the catching up by the followers can be limited. In other words, there are restrictions on the advantages of backwardness (B. Verspagen 1992). The aptitude or not of the countries outdistanced to increase the rate of technological progress depends on the size of the initial lag of knowledge and the intrinsic capacity of the countries to effectively absorb the R\&D spillovers (W.M. Cohen, and D.A. Levindhal, 1989).M. Blomstrom and A. Kokko (1998) showed that the foreign R\&D spillovers are more intensive when the technological lag between them and the local firms are weaker. These authors regard this as coherent with the assumption of the absorptive capacity.

This idea is reinforced by M. Lankhuizen (1998), which while wondering about the factors affecting the process of catching up, insists on the role of the interaction between the absorptive capacity and the initial lag which separates the technological leader and the other countries: the capacity of a country delayed to currently absorb knowledge, is intensified when the initial lag is not very vast. Thus, outdistanced countries must have or create a capacity for sufficient absorption.

We formalize our analysis on the possibilities of the followers to catch up the leader by following M. Lankuizen (1998).We suppose a follower country $F$ with a lag of knowledge $d_{i}$ compared to the technological border. The growth rate of the stock of knowledge of the follower is determined by the growth rate of knowledge resulting from its "exogenic" and technological activities (production and diffusion of new knowledge) $\Psi_{\mathrm{F}}$, and a term of diffusion or spillovers reflecting the advisability for a follower to absorb the technological knowledge of the leader. Therefore, the growth rate of the stock of knowledge can be written as follows:

$$
C_{F}=\Psi_{F}+\gamma_{F} D_{0} e^{(-D}{ }_{0} / \Phi_{F}{ }^{\prime} \quad ; \quad \gamma_{F}, \Phi_{F}>0
$$

The parameters $\gamma_{\mathrm{F}}$ and $\Phi_{\mathrm{F}}$ are specific to the country. The parameter $\Phi_{\mathrm{F}}$, reflects the absorptive capacity of the follower. In measurement that we target our analysis for the catching up by the means of the absorptive capacity, the technological activities specific to the countries are regarded as data. The term of diffusion expresses that there are limits of the advantage of backwardness. The exponential term indicates that with an aim of currently absorbing external knowledge and increasing the growth rate of the stock of knowledge, the initial lag of knowledge should not be very huge and the absorptive capacity must be sufficiently high. For high levels of $\mathrm{D}_{0}$ and given levels of $\Phi_{\mathrm{F}}$, technological opportunities that a follower holds with respect to the technological leader to increase the growth rate of the stock of knowledge through the spillovers is eroded. Moreover, the negative effect (positive) of the broad initial lags (weak and intermediate) on the growth rate of the stock of knowledge in a largely outdistanced country is

\footnotetext{
${ }^{3}$ Empirical studies on convergence generally used method of cross-section and time series. In this case, convergence can be carried out when there is a reduction of the variations in the levels of income on a certain temporal horizon. This type of convergence is observed for the poor countries which grow more quickly than the rich countries ( $\beta$-convergence). Convergence can be also apprehended in the event of reduction of the inter-region variance of the output ( $\sigma$-convergence).
} 
compensated by its absorptive capacity. We evaluate the technological lag in terms of differences in stock of knowledge of the leader and the follower, what implies the following equation:

$$
D=\log \left(C_{L} / C_{F}\right)
$$

In other words, the variation of the technological lag is written as follows:

$$
\Delta D=C_{L}-C_{F}
$$

The notations $\mathrm{L}$ and $\mathrm{F}$ respectively represent the growth rate of the stock of knowledge in the leader and the follower. While replacing (1) in (3), we will obtain the following relation:

$$
\Delta D=\alpha-\gamma_{F} D_{0} e^{-D}{ }_{0} / \Phi_{F}(4) \quad ; \quad \alpha=\Psi_{L}-\Psi_{F}
$$

The dynamic related to this last formulation (4) are such as: the countries which are placed in a way outdistanced compared to the technological border can reduce the lag with respect to the leader if the absorptive capacity is sufficiently high to moreover allow the assimilation of the R\&D spillovers. By opposition, if the absorptive capacity of the follower is too low to be able to compensate the size of the initial lag of knowledge, the follower will continue to fall behind the technological border.

From the analysis of dynamic of the race of the innovation as well as interaction between the absorptive capacity and the initial technological lag, it proves that the effect of the R\&D spillovers is not limited to its negative repercussions on the innovating activity.

This idea is supported by the process of catching up in which the countries which are relatively little lagged compared to the leader and are equipped with a capacity for high absorption can catch up. Moreover, even in the event of the existence of a relatively high lag, the outdistanced countries can catch up, if their absorptive capacity is relatively high to be able to compensate the significant lag.

\section{Intra-industrial and interindustrial $R \& D$ spillovers and exports: empirical application to the Tunisian case}

In what follows, we will try to introduce a model which makes it possible to describe the bond between the national effort of technological innovation, the foreign R\&D spillovers and exports. At this level, we targeted our field of analysis for data of panel of 6 manufacturing sectors: food, beverage and tobacco; mining, quarrying and petroleum; chemicals products; textile, leathers and footwear; basic metals and fabricated metal products; electrical machinery.

The choice of these sectors relies mainly on structural considerations. Indeed, these sectors integrate the production of the intermediate goods, the capital goods and the consumer goods, which makes it possible to avoid any skew of selection. The data considered in our analysis are those covering the period 1987-2007.

\subsection{Specification of the model}

In what follows, we will adopt the methodology developed by Coe and Helpman (1995) in the choice of the matrix of weighting relating to the $R \& D$ spillovers. The latter were focused on the direction of the $R \& D$ spillovers while making interaction between propensity to import and the stock of the foreign R\&D. In other words, the national economy receives more spillovers of the foreign $R \& D$ as the sector considered is intensive in technologies, and that the 
stock of knowledge of the trade partner is considerable. The articulation between the R\&D spillovers and exports must integrate two significant components: the effect of competition and the effect of the R\&D spillovers.

The effect of competition can be appreciated through the increase of the foreign firms market due to the rise of the stock of foreign knowledge what reduces the share of the national firms exports. Moreover, the effect of the R\&D spillovers is observed in the case of a complementarity between foreign and national R\&D. In other words, the effect of the R\&D spillovers on exports is beforehand unknown.

We will integrate in our model an additional variable relating to the rates of real effective exchange. In this case, it is possible to provide that the depreciation of the rate of real effective exchange will involve a rise of exports and conversely. Lastly, we have to integrate another factor conceived from the side of the offer is that relating to gross domestic product. Therefore, our model (model (I)) take the following form:

$$
\mathrm{xn}_{\mathrm{it}}=\alpha_{0}+\alpha_{1} \text { inv }_{\mathrm{it}}+\alpha_{2} \text { exintra }_{\mathrm{it}}+\alpha_{3} \text { exinter }_{\mathrm{it}}+\alpha_{4} \text { ter }_{\mathrm{t}}+\alpha_{5} \mathrm{gdp}_{\mathrm{t}}+\xi_{\mathrm{it}}
$$

Where $\mathrm{xn}_{\mathrm{it}}$ is the logarithm of exports in sector $\mathrm{i}, \mathrm{inv}_{\mathrm{it}}$ is the national technological innovation in sector $\mathrm{i}$, exintra ${ }_{\mathrm{it}}$ is the pool of the foreign $R \& D$ spillovers resulting from sector $i$, exinter ${ }_{i t}$ is the pool of the foreign $R \& D$ spillovers resulting from the other sectors, te $r_{t}$ is the logarithm of the rate of real effective exchange, gdp $_{t}$ is the logarithm of gross domestic product, $\xi$ is the term of error and $t$ is time.

Link (1981) showed that the applied R\&D is ready to be propagated between the countries than the fundamental R\&D insofar as the latter requires a temporal lag largely higher so that it can be transformed into profits of productivity. Thus, we preferred to approximate the $R \& D$ spillovers while making interact between propensity to import and the internal R\&D expenditure of companies (DIRDE) of the countries of our sample.

Therefore, the variables relating to the intra-industrial R\&D spillovers (exintra) and that of interindustrial type (exinter) are respectively formulated in the following way:

$$
\begin{array}{ll}
\text { exintra }_{i t}=\frac{M_{i t}}{\text { PIB }_{t}} \operatorname{Log~DIRDE~}_{i t} & \text { exintra }_{i t}=\frac{M_{i t}}{\text { PIB }_{t}} \operatorname{Log~DIRDE}_{i t} \quad i \neq j \\
\text { exinter }_{i t}=\sum \frac{M_{j t}}{\text { PIB }_{t}} \operatorname{Log~DIRDE~}_{j t} & \text { exinter }_{i t}=\sum \frac{M_{j t}}{\text { PIB }_{\mathrm{t}}} \operatorname{Log~DIRDE}_{j t}
\end{array}
$$

Where exintra is the pool of the intra-industrial and foreign $R \& D$ spillovers coming from sector $i$, exinter is the pool of the interindustrial and foreign $R \& D$ spillovers resulting from the sectors $j, \frac{M_{i t}}{\mathrm{PIB}_{t}}$ is the propensity to import of Tunisia in sector $\mathrm{i}, \frac{\mathrm{M}_{\mathrm{jt}}}{\mathrm{PIB}_{\mathrm{t}}}$ is the propensity to import of Tunisia in the sector J, DIRDE are the internal R\&D expenditure of the foreign companies and $\mathrm{t}$ is time.

In addition, to emphasize the temporal dimension of the transmission of international technological knowledge, we have to integrate a temporal lag in the measurement of the foreign R\&D spillovers. Therefore, we based ourselves on the Akaike Information Criterion (AIC) and the Schwartz Information Criterion (BIC) to select an optimal number of lags necessary to the transmission of the foreign R\&D spillovers which they are intra-industrial or interindustrial.

We focus ourselves particularly on the choice between the current R\&D spillovers (lag $=0)$ and those lagged by one and two years $(\operatorname{lag}=1,2)$. 
Table no 1:Akaike Information Criterion (AIC) and Bayasien Information Criterion of Schwartz (BIC): Choice of the optimal number of lags.

\begin{tabular}{|l|c|c|c|}
\hline Lag & Variable & AIC & BIC \\
\hline Lag $=0$ & $\begin{array}{l}\text { Exintrat } \\
\text { Exintert }\end{array}$ & 300.3066 & 317.3243 \\
\hline \multirow{2}{*}{ Lag $=0,1$} & $\begin{array}{c}\text { Exintrat } \\
\text { Exintert }_{-1}\end{array}$ & 283.277 & 300.002 \\
\cline { 2 - 4 } & $\begin{array}{l}\text { Exintrat }_{-1} \\
\text { Exintert }\end{array}$ & 282.050 & 298.775 \\
\hline Lag $=1$ & $\begin{array}{l}\text { Exintrat }_{-1} \\
\text { Exintert }_{-1}\end{array}$ & 284.248 & 300.972 \\
\hline \multirow{2}{*}{ Lag $=1,2$} & $\begin{array}{l}\text { Exintrat }_{-1} \\
\text { Exintert }_{-2}\end{array}$ & 269.703 & 286.120 \\
\cline { 2 - 4 } & $\begin{array}{l}\text { Exintrat } \\
-2 \\
\text { Exintert }_{-1}\end{array}$ & 272.851 & 289.269 \\
\hline \multirow{2}{*}{ Lag $=2$} & $\begin{array}{l}\text { Exintrat }_{-2} \\
\text { Exintert }_{-2}\end{array}$ & 273.967 & 290.384 \\
\hline
\end{tabular}

The optimal number of lags is that which makes it possible to minimize the Akaike Information Criterion (AIC) and Schwartz Information Criterion (BIC). At this level, table $\mathrm{n}^{\circ} 1$ indicates that a number of lags of one year for the intraindustrial R\&D spillovers and two years for the interindustrial R\&D spillover are necessary to specify our model. Therefore, a second regression of the model (I) takes the following form (model II):

$$
\mathrm{xn}_{\mathrm{it}}=\alpha_{0}+\alpha_{1} \text { inv }_{\mathrm{it}}+\alpha_{2} \text { exintra }_{\mathrm{it}-1}+\alpha_{3} \text { exinter }_{\mathrm{it}-2}+\alpha_{4} \text { ter }_{\mathrm{t}}+\alpha_{5} \text { gdp }_{\mathrm{t}}+\xi_{\mathrm{it}}
$$

Where exintra $\mathrm{it}_{\mathrm{it}-1}$ is the pool of the intra-industrial $\mathrm{R} \& \mathrm{D}$ spillovers lagged by one year and exinter $\mathrm{it}_{2}$ is the pool of the interindustrial $R \& D$ spillovers lagged by two years.

The presence of lags different from zero in the measurement of the foreign R\&D spillovers that they are inraindustrial or interindustrial, makes it possible to stress a significant aspect of the R\&D spillovers: the difficulties encountered during the transmission and the assimilation of the external R\&D. In other words, low absorptive capacity of the foreign R\&D spillovers.

In order to harmonize the data relating to exports and those relating to the foreign R\&D spillovers, we chose to resort to the standard international classification of industry (ISIC rev.3), available in the data base of OECD ${ }^{4}$.

At this level, the procedure adopted by Tunisia for the classification of the products is that based on the nomenclature of the harmonized system (NSH). To ensure the correspondence between the standard international classification of industry, and the nomenclature of the harmonized system we based ourselves on the table of correspondence worked out by the United Nations 5 .

\footnotetext{
${ }^{4}$ Site Internet: http://stats.oecd.org/Index.aspx?DataSetCode=ANBERD_REV3

${ }^{5}$ Site Internet: http://ec.europa.eu/eurostat/ramon/relations/index.cfm?TargetUrl=LST_REL\&StrLanguage

Code $=$ FR \& IntCurrentPage $=4$.
} 
Moreover, considering the unavailability of the data of the sectorial R\&D expenditure, we have to resort to the outputs of the R\&D instead of the inputs of the $R \& D$ to evaluate the efforts of the domestic R\&D.

At this level, Griliches (1979) showed that the patents constitute a relevant indicator of the output of the R\&D. Thus, we approximated the national effort of technological innovation by the number of patents deposited by the residents at the sectorial level.

\subsection{Results of the estimates}

Our first stage consists in checking the presence of individual effects in our data. In this case, the test of the existence of individual specificities based on the statistics of Fisher indicates the existence of a homogeneity of the coefficients of the models (I) and (II). Thus, the use of the method of panel can be justified. The test of Fisher also shows the presence of significant individual effects.

To determinate the nature of the individual effects, we resorted to the test of Hausman which makes it possible to test if the coefficients of the two estimates (fixed and random) are statistically different. In other words, the test of specification of Hausman makes it possible to choose between the fixed effects model and the random effects model.

At this level, our results exposed in table $\mathrm{n}^{\circ} 2$ show that the probability of the test of Chi2 is higher than $10 \%$ (pvalue $=0.981$ for the model (I) and $p$-value $=0.953$ for the model (II)), which translates that one cannot reject the null assumption of absence of correlation between the individual effects and the explanatory variables. In other words, the models (I) and (II) can be specified with random individual effects.

Table no 2: Tests of specification of the individual effects, Number of sectors:6, Period: 1987-2007

\begin{tabular}{|c|c|c|c|c|}
\hline & \multicolumn{2}{|l|}{ model (I) } & \multicolumn{2}{|l|}{ model (II) } \\
\hline & $\begin{array}{l}\text { Value of Chi2 } \\
\text { (p-value) }\end{array}$ & $\begin{array}{l}\text { Value of F } \\
\text { (p-value) }\end{array}$ & $\begin{array}{l}\text { Value of Chi2 } \\
\text { (p-value) }\end{array}$ & $\begin{array}{l}\text { Value of F } \\
\text { (p-value) }\end{array}$ \\
\hline Test of Fisher & & $\begin{array}{r}\mathrm{F}(5,115)=85.44 \\
\mathrm{p} \text {-value }=0.000\end{array}$ & & $\begin{array}{c}F(5,103)=86.82 \\
\text { p-value }=0.000\end{array}$ \\
\hline Test of Hausman & $\begin{array}{c}\text { Chi2(5) }=0.74 \\
(\mathrm{p} \text {-value }=0.981)\end{array}$ & & $\begin{array}{l}\text { Chi2(5)=1.11 } \\
\text { p-value }=0.953\end{array}$ & \\
\hline Test of Breush- Pagan & $\begin{array}{l}\text { Chi2 }(1)=674.49 \\
(p \text {-value }=0.000)\end{array}$ & & $\begin{array}{c}\text { chi2 }(1)=560.13 \\
\text { p-value }=0.000\end{array}$ & \\
\hline $\begin{array}{l}\text { Number of } \\
\text { observations }\end{array}$ & & 126 & & 14 \\
\hline
\end{tabular}

Moreover, the test of Breush-Pagan shows the presence of significant random effects. Indeed, the probability of the statistics of Breush-Pagan shows that the random effects are significant at the threshold of $1 \%$ ( $\mathrm{p}$-value $=0.000$ for the models (I) and (II)). 
After having specified the nature of the individual effects, we proceeded for the detection of the heterosedasticity.In this case, we used the procedure based on the test of Breush-Pagan which consists in testing the null assumption of homoscedasticity. Our results show that one cannot accept the null assumption and thus the presence of heterosedasticity in the models (I) and (II).

In order to obtain more information on the form of heterosedasticity, we used the test of modified Wald. This test is used with an aim of testing the specific assumption of inter-individuals homoscedasticity, and thus, testing the following null assumption: the variance of the errors is the same one for all the individuals $\left(\sigma_{i}^{2}=\sigma^{2}\right.$ for any individual I $=1 \ldots \mathrm{N})$.

Table no 3:Tests of heteroscedasticity, Random effect modelsNumber of sectors:6, Period:1987-2007

\begin{tabular}{|c|c|c|c|c|}
\hline & \multicolumn{2}{|l|}{ Model (I) } & \multicolumn{2}{|l|}{ Model (II) } \\
\hline & $\begin{array}{l}\text { Value of Chi2 } \\
\text { (p-value) }\end{array}$ & $\begin{array}{l}\text { Value of } F \\
\text { (p-value) }\end{array}$ & $\begin{array}{l}\text { Value of Chi2 } \\
\text { (p-value) }\end{array}$ & $\begin{array}{l}\text { Value of F } \\
\text { (p-value) }\end{array}$ \\
\hline Test of Breush-Pagan & & $\begin{aligned} F(5,120) & =6133.63 \\
\text { p-value } & =0.000\end{aligned}$ & & $\begin{array}{l}F(5,108)=7309.0 \\
6 \\
p \text {-value }=0.000\end{array}$ \\
\hline $\begin{array}{l}\text { Test of modified } \\
\text { Wald }\end{array}$ & $\begin{array}{l}\text { Chi2 (6) }=243.41 \\
\text { p-value }=0.000\end{array}$ & & $\begin{aligned} \text { Chi2 }(6) & =160.81 \\
\text { p-value } & =0.000\end{aligned}$ & \\
\hline $\begin{array}{l}\text { Number of } \\
\text { observations }\end{array}$ & & 126 & & 114 \\
\hline
\end{tabular}

Our results show that one cannot accept the null assumption. The rejection of the null assumption does not enable us to more specify the structure of the heteroscedasticity in the models (I) and (II) at the same time. Therefore, one remains with the heteroscedasticity $\sigma_{\text {it }}{ }^{2} \neq \sigma^{2}$ for any individual $i$ and time $t$ without being able to specify its nature more of it.

Lastly, we tested the presence of autocorrelation by basing us on the test of contemporary correlation between individuals of Breush-Pagan, and the test of intra-individuals autocorrelation of Wooldridge.

From table no 4, the test of Breush-Pagan based on the statistics of Chi2 shows that one cannot reject the null assumption of independence of the residues between the individuals in the model (I), and therefore, the errors are not correlated in a contemporary way between the individuals ( $\mathrm{p}$-value $=0.1001)$. By opposition, the same test shows the absence of independence of the errors between the individuals when it is about the model (II) ( $\mathrm{p}$-value $=0.003$ ).

Table no 4:Tests of autocorrelation of the errors, Random effects modelsNumber of sectors:6, Period:1987-2007

\begin{tabular}{|l|l|l|l|l|}
\hline & \multicolumn{2}{|l|}{ Model (I) } & \multicolumn{2}{l|}{ Model (II) } \\
\hline & $\begin{array}{l}\text { Value of Chi2 } \\
\text { (p-value) }\end{array}$ & $\begin{array}{l}\text { Value of F } \\
\text { (p-value) }\end{array}$ & $\begin{array}{l}\text { Value of Chi2 } \\
\text { (p-value) }\end{array}$ & $\begin{array}{l}\text { Value of F } \\
\text { (p-value) }\end{array}$ \\
\hline
\end{tabular}




\begin{tabular}{|l|c|c|c|c|}
\hline $\begin{array}{l}\text { Test of Breush- } \\
\text { Pagan }\end{array}$ & Chi2(15)=22.303 & & $\begin{array}{c}\text { Chi2 }(15)=34.077 \\
\text { p-value }=0.003\end{array}$ \\
\hline Test of Wooldridge & & $F(1,5)=23.282$ & & \\
& & p-value=0.005 & & p 1,5$)=16.571$ \\
& & & & \\
\hline $\begin{array}{l}\text { Number of } \\
\text { observations }\end{array}$ & 126 & & \\
\hline
\end{tabular}

Concerning the intra-individuals autocorrelation, the test of Wooldridge whose null assumption is the absence of autocorrelation of first order of the residues (see Wooldridge 2002) shows that the errors of the individuals are autocorrelated in the models (I) and (II) at the same time ( $\mathrm{p}$-value $=0.005$ and $\mathrm{p}$-value $=0.01$ respectively).

As a conclusion, our econometric analysis shows that the models (I) and (II) incorporate random effects with the presence of the heterosedasticity and the intra-individuals autocorrelation. Therefore, the estimator of generalized least squares (GLS) led to not skewed results.As shown by the table no 5, the estimate of the model (I) reveals positive and significant effect of the current and foreign R\&D spillovers of intra-industrial type on national exports.

Table no 5:Results of the estimates, Dependent variable:exports (xn), Random effect models, Numbers of sectors:6 Period:1987-2007

\begin{tabular}{|l|c|c|}
\hline $\mathrm{Xn}$ & \multicolumn{1}{|l|}{ Model (I) } & Model (II) \\
\hline Inv & Coefficient & Coefficient \\
\hline $\begin{array}{l}\text { exintra }_{\mathrm{t}} \\
\text { exintra }_{\mathrm{t}-1} \\
\text { exinter } \\
\mathrm{t}\end{array}$ & $1.275^{* * * *}$ & 0.006 \\
\hline exinter $\mathrm{t}_{\mathrm{t}-2}$ & 0.137 & $1.565^{* * *}$ \\
\hline GDP & $1.105 * * *$ & $1.192^{* * * *}$ \\
\hline Ter & -0.285 & -0.620 \\
\hline Constant & $-5.628 * * *$ & $-5.432 * * *$ \\
\hline
\end{tabular}




\begin{tabular}{|l|c|c|}
\hline N.Obs. & 126 & 114 \\
\hline $\begin{array}{l}\text { Criteria of } \\
\text { information }\end{array}$ & $\mathrm{AIC}=365.872$ & $\mathrm{AIC}=342.911$ \\
$\mathrm{BIC}=382.890$ & $\mathrm{BIC}=359.636$ \\
\hline $\mathrm{R}^{2}$ & $\begin{array}{l}\text { within }= \\
0.774 \\
\text { between }=0.563\end{array}$ & $\begin{array}{l}\text { within }=0.745 \\
\text { between }=0.533 \\
\text { averall }-0.514\end{array}$ \\
\hline
\end{tabular}

(***) Significativity at the threshold of $1 \%$.

(*) Significativity at the threshold of $10 \%$.

The estimate of the model (II) supports also the importance of the same type of spillovers to stimulate international competitiveness based on exports when they are lagged by one year: an increase of $1 \%$ of the pool of the intra-industrial R\&D spillovers lagged by one year exerts $1.565 \%$ of additional growth of national exports.

These results emphasize the role of the complementarity between the national R\&D and foreign and intrasectorial R\&D spillovers in the stimulation of international competitiveness. Indeed, the R\&D spillovers resulting from the same sector are easier to assimilate than those emanating from other sectors having relatively different characteristics. This idea is reinforced by our results of the estimates of the models (I) and (II): the current and interindustrial foreign $R \& D$ spillovers do not exert any significant effect on exports. Moreover, the interindustrial and foreign R\&D spillovers lagged by two years exert negative and significant effects on exports.

In other words, the effect of the spillovers overrides the effect of competition when they are intra-industrial and foreign $\mathrm{R} \& \mathrm{D}$ spillovers and conversely for the interindustrial and foreign R\&D spillovers.

This idea is consolidated before by the choice of the model to estimate insofar as the criteria of information of Akaike (AIC) and Schwartz (BIC) are placed in favour of a more dug temporal lag of the interindustrial R\&D spillovers compared to those of intra-industrial type: the first type of spillovers requires two years as temporal lag whereas the second type requires only one year of lag.

In addition, our results of the estimates put in accent the positive and significant effects of the gross domestic product on exports: the estimate of the model (II) shows that an increase in $1 \%$ of the gdp enhances national exports by $1.192 \%$ (and $1.1 \%$ when it is about the model (I)).

From table no 5, one notes that the national technological innovation exerts an effect not significantly different from zero on national exports. This result translates the fact that the efforts of national technological innovation are targeted to preserve the shares of the market to export and not to impel their values of them, and that Tunisia is still captive in its initial specialization without there being sufficient changes in direction of the promising and highly technological sectors. Our results of the estimates also show the absence of significant effects of the rate of real effective exchange on exports.

Starting from the above mentioned results, our empirical analysis supports the assumption of the role assigned with the absorptive capacity of the foreign $R \& D$ and intra-industrial spillovers in the stimulation of national exports. Indeed, the international competitiveness of Tunisia seems to be conditioned by the intra-industrial and foreign $R \& D$ spillovers that by its own efforts of technological innovation. 


\section{Conclusion}

Our analysis shows that the intra-industrial and foreign R\&D spillovers which they are instantaneous or lagged by one year exert at the same time positive and significant effects on national exports.

By opposition, the interindustrial and foreign R\&D spillovers even when they are shifted in time do not exert any positive and significant effect on exports. In other words, the effect of the foreign R\&D spillovers overrides the effect of competition when they are intra-industrial and conversely for the interindustrial and foreign R\&D spillovers.

In the light of the above mentioned results, our empirical analysis supports the assumption of the role assigned with the absorptive capacity of the foreign $R \& D$ and intra-industrial spillovers in the stimulation of national exports. Indeed, the international competitiveness of Tunisia seems to be conditioned by the intra-industrial and foreign $R \& D$ spillovers that by his own system of technological innovation.

\section{References}

Blomstrom M. and Kokko A. (1998), Multinational corporations and spillovers, Journal of Economic Survey, 12 (3), pp. 247-277.

Coe D. T. and Helpman E. (1995), International R\&D spillovers, European Economic Review 39, pp. 859-887.

Cohen, W.M. and Levindhal, D.A. (1989), Innovation and Learning: The Two Faces of R\&D, The Economic Journal, 94, pp. 569-596.

Griliches Z. (1979), Issues in assessing the contributions of R\&D to productivity growth, Bell Journal of Economics, 10 (1), pp.92-116.

Grossman G. M. and Shapiro C. (1987), Dynamic R\&D competition, The Economic Journal, pp.372-387.

Halmenschlager C. (2003), Les externalités de diffusion du savoir-faire permettent- elles de rattraper le retard dans les courses à l'innovation?, Site Internet: www.u.paris2.fr/clermes/doctrav/trav0304.

Hausman J.A. (1978), Specification Tests in Econometrics, Econometrica, 46, pp. 1251-1271.

Klette and Griliches Z. (2000), Empirical patterns of firm growth and R\&D investment: A quality ladder model interpretation, The Economic Journal, 110, pp. 363-387.

Lankhuizen M. (1998), Catching Up, Absorption Capacity and the Organisation of Human capital: Research

Memoranda, 017 /. 98. 2002. MERIT.

Lee T. and Wilde L. (1980), Market Structure and Innovation: A Reformulation, Quarterly Journal of Economics, 94, p. 429.

Link A. (1981), Basic research and productivity increase in manufacturing: Additional evidence, American Economic Review, 71 (5), pp.1111-1112.

Lowery D. (1979), The Meaning of Property Rights. American Political Science Review. 73 (Mars), pp. 190-191.

Romer P. M. (1990), Endogenous technological change, Journal of Political Economy, vol. 98, p. S71-S102.

Tarek B. H. (2012), Absorptive capacity, R\&D spillovers and product variety: Empirical evidence for the case of Tunisia, Journal Of Business and Economics, Vol. 3 No. 2, pp.235-269

Verspagen B. (1992), Uneven Growth between Interdependent Economies. An Evolutionary View on Technology Gaps, Trade and Growth, Maastricht: Universitaire Pers Maastricht.

Wooldridge J. (2002), Econometric Analysis of Cross Section and Panel Data, Cambrige, The MIT Press. 